\title{
"The Evangelical Revival in Britain: The Foundation of the Church Missionary Society and its Early Work in the Muslim World"
}

\author{
Nacera Mamache $^{1 *}$, Fatiha DANI ${ }^{2}$ \\ ${ }^{1}$ Doctoral Student, University of Oran 2, Mohamed Ben Ahmed, Algeria \\ Email: nbmamache@gmail.com \\ ${ }^{2}$ Supervisor, Professor, University of Oran 2, Mohamed Ben Ahmed, Algeria \\ Email: fatjhadani@yahoo.fr
}

DOI: $10.36348 /$ SJHSS.2019.v04i10.005

| Received: 08.10.2019 | Accepted: 18.10.2019 | Published: 30.10.2019

*Corresponding author: Nacera Mamache

\section{Abstract}

Synopsis: This article explores the state of the Church and the religious life in England prior to the Religious Revival, the rise of the Evangelical Movement and the subsequent foundation of the Church Missionary Society and its early missionary activity in the Muslim world. The Evangelical Movement in Britain led, eventually, to the formation of a large number of missionary societies including the Church Missionary Society; an important medium of the Church of England in spreading Christianity around the globe in general and in the Muslim world in particular.

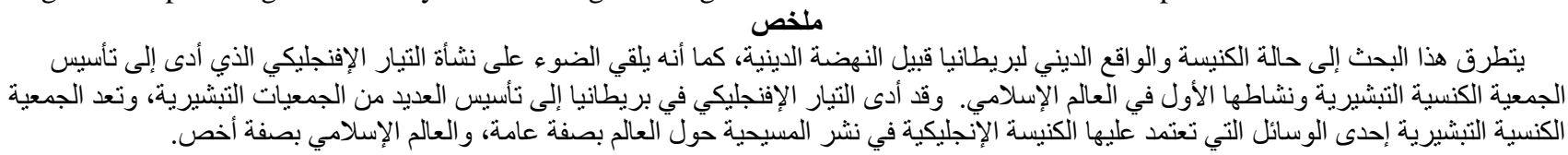

Keywords: Religious Revival, Church of England, Church Missionary Society, Missionary work, Muslim World.

\begin{abstract}
Copyright @ 2019: This is an open-access article distributed under the terms of the Creative Commons Attribution license which permits unrestricted use, distribution, and reproduction in any medium for non-commercial use (NonCommercial, or CC-BY-NC) provided the original author and source are credited.
\end{abstract}

\section{INTRODUCTION}

This article explores the state of the Church and the religious life in England prior to the Religious Revival, the rise of the Evangelical Movement and the subsequent foundation of the Church Missionary Society and its early missionary activity in the Muslim world. The Evangelical Movement had a direct impact on the birth of a large number of missionary societies including the Church Missionary Society which stands as the right arm of the Church of England in spreading Christianity in the Muslim world and around the globe.

\section{State of the Church and the Religious life in England prior to the}

\section{Evangelical Revival}

The early eighteenth century, more precisely by 1738 , was marked by a collapse in the standards of morality and religion in England reaching "a degree that was never before known in any Christian country" as declared by Bishop Berkeley [1]. The degeneracy of moral and religious standards of this time was beyond dispute. England at that time is described as:

"Full with moral corruption and crippled by moral decay'. Most Englishmen of the day considered that a life of unrestrained licentiousness could be indulged in with impunity, and with this frame of mind, much of the nation threw off restraint and plunged itself headlong into godless living. Bishop Ryle says: '...suffice to say that duelling, adultery, fornication, gambling, swearing, Sabbath-breaking and drunkenness were hardly regarded as vices at all. They were the fashionable practices of people in the highest ranks of society, and no one was thought the worse for indulging in them [2]."

1- John Dunn, "The Great Evangelical Awakening of the Eighteenth Century" New Creation Publications Inc. PO Box 403, Blackwood, South Australia 5051 1983, First published December 1983 (C) 1983 John Dunn ISBN 0 86408007 7, p 2. 
2- Donald Drew, England Before and After Wesley By Donald Drew, http://www.disciplenations.org/media/England-Beforeand-After-Wesley_Drew.pdf, p 1.

This state of affairs is attributed to a number of reasons where three of them are pinpointed as most outstanding: First, The punitive and anti-Puritan legislation known as the Clarendon Code (16611665) under Charles II. About these laws, Donald Drew argues:

"These stabbed at the heart of Puritan legislation, religion, education and culture. Nearly onefifth of all British clergy - those who opposed the Act of Uniformity-were expelled from the Church of England. In their stead, cavalier place seekers were installed. The overall result was the near extinction of biblical thinking and conduct amongst most clergy. In next to no time, the dead hand of worldliness had settled upon the Church [3]."

Second, William of Orange reign (1689-1702) witnessed the expulsion of Non-Jurors [4]. The latter were more than four hundred Anglican clergies who refused to take the Oath of Allegiance. William's legislation is interpreted as depriving the Church of priests whose posts were replaced with mediocrities [5].

3- "The Nonjurors were a group of Anglican clergy who, after the "Glorious Revolution" of 1688 in which Parliament deposed King James II and installed William and Mary, refused to take an oath to the new monarchs, believing that would violate their oath to the previous king. Most were "high-church", and included several bishops and another high-ranking clergy. Because they would not swear allegiance to the new king and queen, they were relieved of their "livings", or positions, and forced to seek support on their own. http://justus.anglican.org/resources/bcp/Nonjurors.htm// Accessed on 29/09/2017.

4- Donald Drew, op cit, $\mathrm{p} 1$.

5- Convocation is a meeting of a religious character as distinguished from the congregation, which was more general, dealing with political and legal matters. Hence it is called a "holy convocation."Source: http://www.biblestudytools.com/dictionary/convocation/ /Accessed on 20/09/2017.

The third reason causing religious degeneracy is attributed to the suppression of Convocation [6] as a result of which Anglican bishops and clergy were forbidden to congregate officially for the deliberation of ecclesiastical issues. As the law remained in vigour until the nineteenth century; a matter which pushed the clergy to behave on independent initiative [7]. This situation is considered responsible for the unreligious character of the eighteenth-century church and people, in addition to the influence of Enlightenment by the end of the seventeenth and throughout the eighteenth centuries of Deism [8] or natural religion [9]. Describing the lamentable state of the church Donald Drew further argues:
"A national Church publicly muzzled, with its prophetic and priestly wings clipped, was in no position to refute Deists and sceptics. Religion was squeezed into a formalized straight jacket. The inevitable progression took place: from Deism to rationalism to scepticism to cynicism.[10]".

6- Donald Drew, op cit, $\mathrm{p} 1$

7- "Deism is a theological position that upholds a belief in God as a creator of the world but rejects the concept of divine revelation (including miracles and supernatural events). More broadly, Deism refers to a cluster of philosophical and theological ideas that flourished in Europe and North American during the Enlightenment and led to a thorough critique of Christian orthodoxy./ Ref: Encyclopedia of Religion and Nature (London \& New York: Continuum, 2005), Edited by Bron Taylor, $p$ 462.

8- Natural Religion: a religion validated on the basis of human reason and experience apart from miraculous or supernatural revelation; specifically: a religion that is universally discernible by all men through the use of human reason apart from any special revelation./ Source: /http://www.merriam webster.com/dictionary/natural\%20religion.

9- Donald Drew, op cit, p 2.

10- John Dunn, op. cit., p 2.

John Dunn also argues about the state of the churches of the establishment in general saying:

"Almost without exception, the churches of the Establishment were dead and formal. From many pulpits, a sermon could not be heard from one month's end to the next, and of the 10,000 clergies in the Church of England, only a tiny handful struggled to maintain the Truth. The chapels of the Dissenters were for the most part deserted, but where sermons were from time to time preached, these were little better than moral essays, devoid of anything to awaken souls, and deadening both to preacher and hearer alike. The vast majority of the parochial clergy were sunk in worldliness [11]."

As a result of the policy adopted towards Puritanism and the impact of Deism in the mieighteenth century, the majority of the clergy of the Church of England lived in corruption. Archbishops neglected their religious duties and adopted a luxurious living. Further events contributed to the degeneracy of the religious life in Britain. The treaty of Utrecht (1713) gave the monopoly of the slave trade to England; a matter which engendered brutality towards slaves. Also, the Industrial Revolution led to the ill-treatment of workers. The nation was, accordingly, divided into rich and poor with the implementation of laws that were meant to be maintained. ${ }^{\mathbf{1 2}}$ Furthermore, libertinism was the medium of literary expression, evil and licentiousness filled the length and breadth of society to the extent that it was observed in 1751 that "One is 
forced to travel, even at noon, as if one were going to battle [13]."

11- Donald Drew, Ibid, pp 2, 3.

12- Ibid, p 4

13- John Dunn, Ibid, Introduction

\section{The Evangelical Revival and its Effects}

The Evangelical Revival of the eighteenth century was a movement that emerged from within the Church of England. It worked for the revival of Biblical Christianity and it led to the Great Evangelical Awakening within society. It was a sweeping movement that reached not only all the parts of Great Britain but also Europe and the New England colonies of North America. The importance of the movement of Revival is considered second to that of the Reformation. Starting in the 1730's, it signalled a new direction in the religious history of England and it changed the lives of people who were drifted by temptations and corruption [14].

Prominent among the figures of this movement was George Whitefield (1714-1770) who was a student at the University of Oxford in 1732. In that same year, the Wesley brothers; Charles and John met with George Whitefield in Oxford and their meeting came to known as the 'Holy Club'. They were labelled 'Methodists' for the strict and self-disciplined way of life they adopted. Both Charles Wesley and his brother John were ordained in the Church of England [15].

Charles Wesley and some of the Revivalist followers, after being adherents for a long time to the Church of England, ended up by withdrawing from it while many others chose to remain within the established Church [16]. Charles and his brother first sailed to America. On his return to England, Charles began preaching among prisoners, workhouses and other places. George Whitefield was the forerunner of field preaching.

14- John Dunn, Ibid, p 6

15- https://www.britannica.com/topic/AnglicanEvangelical\#ref84601. Accessed on 21/09/17 at $7 / 49 \mathrm{pm}$

16- John Dunn, Ibid, p 14

In 1739, Charles was convinced of fieldpreaching as an approach to reach the masses of English people who were unreached by the Church of England. With the open-air sermons, the Evangelical Revival began. On many occasions, the two Wesley brothers and Whitfield were assaulted and managed to escape death. Even Anglican clergy ill-treated Charles Wesley and described him as "that mystery of iniquity", "a diabolical seducer, and impostor and fanatic» On the response occasioned by Wesley's preaching it is argued:
"As we can well imagine, all this colossal activity occasioned great opposition. Wesley was often in danger of losing his life and was assaulted by violent and semi-heathen mobs on a number of occasions. $\mathrm{He}$ was denounced by the bishops as an enthusiast, a fanatic, and a sower of discontent. $\mathrm{He}$ was often preached against by the parochial clergy and held up to scorn as a heretic [17]'.

Furthermore, it is pointed out that the work of the Evangelical Revivalists generated a pervasive fear and abhorrence of religious zeal among the English whose memories of the wars of the seventeenth century were believed to be stirred by religious zealots [18].

Wesley adhered to the idea that the basic message of the Bible is the guiding of sinners back to God through the atoning sacrifice of Jesus Christ. His thought was also pregnant with the idea that social change is inevitably the outcome of conversion [19]. Conversion led, eventually, to the organization of English people into Societies.

17- John Dunn, Ibid, p 3

18- http://www.disciplenations.org/media/England -Before-and-After Wesley_Drew.pdf, p5

19- Ibid, pp 5,6

Initially, Charles Wesley adhered to Church of England for the most part of his life. Yet, his break with the Church of England came after he started ordaining ministers to the Methodist church. His preaching resulted in increased conversion of all those who strayed from the path of Christianity. The first Methodist preaching house- Evangelical group meeting place- was established in 1739 in Bristol, followed by others in England, Scotland and Ireland. Unflaggingly, between 1739 to his death in 1791, he organized hundreds of local Methodist Societies; he founded a free dispensary for the poor, and a rheumatism clinic in London. Charles Wesley was also the publisher of three-hundred and thirty books and preached forty-five thousand sermons [20]. Wesley, Whitfield and other Evangelical Revivalists worked for the revitalization and fortification of the conservative theology [21] which was tuned towards Presbyterianism [22]. Their work is considered as a significant contribution and a successful return to the Bible which is compared to saving Britain "from lapsing into infidelity [23]."

20- The battle cry of the Reformation was sola Scriptura $^{6}$ The principle of the Bible alone meant not only the priority of Scripture over church and tradition but also its priority overall methods of obtaining knowledge. Source: https://www.ministrymagazine.org/archive/197 7/10/a-conservative-approach-to-theology.

21- "Presbyterianism: A form of Protestant Church government in which the Church is administered locally by the minister with a group of elected elders of equal rank, and regionally and nationally by representative 
courts of ministers and elders."/ source: https://en.oxforddictionaries.com/definition/pre sbyterianism

22- Donald Drew, Ibid, p 7.

23- John Dunn, Ibid, p 11

While sharing Evangelicalism in common, Charles Wesley differed from George Whitefield in management. Charles is said to be an organizer and an administrator. He was successful in organizing a large number of converts into Societies that developed into the Methodist denomination [24].

Among the immediate outcomes of the Evangelical movement was the effecting of a Great Awakening that led to the raising of the standards of morality within the nation. John Dunn writes about this Great Revival saying:

"[It] changed in a few years the temper of English society. The Church was restored to life and activity [25]." Wesley' work was of a great impact on the political leaders of the country. Wilberforce, for instance, was a staunch defender of the cause of slavery and [26] Lord Shaftsbury [27] (1801- 1885), was a British politician, philanthropist and reformer. The Evangelical Revival led also to the development of the Clapham group [28] (1790-1830). Writing about the effects of the Revival, Dunn writes:

24- John Dunn, Ibid, p 14

25- "William Wilberforce was an English politician who became the voice of the abolition movement in Parliament. Around 1784-1786, he underwent a gradual but intense religious conversion. He championed many causes, but it was the fight against the Slave Trade and slavery that he worked most tirelessly for. Finally, on 25th March, the Abolition of the Slave Trade Act abolished the Slave Trade in the British colonies. Source: http://abolition.e2bn.org/people_24.html

26- "Lord Shaftesbury was known as the Reforming Lord Shaftesbury and the Poor Man's Earl, because many of the reforms he championed helped the poor and the working class of Victorian Britain."

27- "The Clapham Sect was a group of English Christian Evangelicals, who between 1790 and 1830 , supported the abolition of slavery and promoted missionary work at home and abroad. The sect was led by John Venn. The Clapham Sect included businessmen, bankers, politicians, and colonial governors, members of Parliament, who worked for the benefit of people at home and abroad." https://www.britannica.com/topic/ClaphamSect

28- John Dunn, Ibid, p 15

"Much, much more could be said of the effects of the revival. It was the beginnings of the modern missionary movement; Sunday Schools started as a result; there was an upsurge in the printing of Christian literature; the first Bible Schools were established; there were a host of social, legal and political reforms as men's consciences became more attuned to the Word of God. There were changes to the penal system and the beginning of the modern medical and educational structures which we take so much for granted [29]."

By the end of the nineteenth and the beginning of the twentieth century, the Church of England maintained its status of the Church of the establishment. Congregationalists and Presbyterians, and other Protestant Free Churches contributed tremendously in the religious, cultural and political life of England. The penal laws, imposed on dissenters after the restoration, were mostly abolished and the free churches played a significant role in the civic life in cities like Birmingham. By the second half of the nineteenth century, it was declared that:

"The affairs of Birmingham were decided in the vestry of Carr's Lane Congregational Chapel whose minister, R. W. Dale, played a leading part in the political as well as the religious life of the city. There were continuing tensions between the Church of England and the Free Churches over issues such as tithes and the role of the Church of England in the education system, but overall relations between them were improving. However, the divisions between the churches remained [30]."

29- General Synod Relations with the United Reformed Church: A report by the Council for Christian Unity, to which is appended Healing the Past- Building the Future: Report of A Church of England - United Reformed Church Study Group/ https://www.churchofengland.org/media/20029 29/healing\%20the\%20past \%20building\%20the $\% 20$ future.pdf,p 5

30- Idem,

The Lambeth Appeal of 1920 was marked by an effort towards reconciliation in the division of the confessional pluralism in England that existed between the Anglicans, Congregationalists and Presbyterians as a result of the Civil War and the Great Ejection (1662). In 1920 the Lambeth Conference of Anglican Bishops issued an Appeal to all Christian People in which it declared that:

"The time has come...for all separated groups of Christians to agree in forgetting the things which are behind and reaching out to the goal of a reunited Catholic Church [31].

\section{Pluralism within the Church of England}

One of the outstanding results of the Evangelical Revival was that it gave rise to various missionary societies like the Baptist Missionary Society (1792), The London Missionary Society (1795), The Wesleyan Mission Society (1786), The British and 
Foreign Bible Society (1804), The China Inland Mission (1865). The missionary society of our concern in this research is the Church Missionary Society (1799). The Evangelical Revival generated a missionary ambition which carried Christian message all over the globe. $^{32}$

31- Donald Drew, p 10.

32- "SELINA, Countess of Huntingdon, was born in 1707; she was a member of the Church of England. She used her influence to arrange the appointment of evangelical clergymen in numerous parishes. The Countess opened private chapels attached to her residences, which she was allowed to do as a peeress of the realm. These were used for the public preaching of the gospel, but they became a source of contention from the local Anglican clergy, she reluctantly seceded from the Church of England in 1781" http://www.cofhconnexion.org.uk/history/ Accessed on 29/09/2017).

The CMS was an offspring of the Evangelical Revival. It was commenced by a group of clergymen from the Anglican Church known as the Clapham Sect or Claphemists. Like other revivalists, they were confronted with the question of working within the established Church of England. The revivalists were critical of the leaders of the Anglican Church and its liturgies. Unlike his brother Charles, John Wesley kept live ambitions to reform the Anglican Church and refused to leave the Church and get the status of a dissenter. Charles, however, spent the most part of his life as an ordained Anglican minister. Finding impossible to achieve reform, he ended by establishing the Methodist Church with other Evangelicals.

When John Wesley died in 1791, three denominations emerged among those who came to be known as Methodists or Evangelicals. First, there was the Wesleyan Methodist denomination distinguished by its singing of hymns. As opposed to the parish churches of the established Anglican Church, the Wesleyan Methodists' places of worship were authorized as dissenting chapels.

Second, the Calvinist Methodist denomination emerged under the leadership of George Whitefield. The patronage of Countess Huntington/ Huntingdon (1707-1791)[33] led to the association of some members of the aristocracy who provided funding to the denomination.

33- J. F. Ade. Ajayi. "From Mission to Church: The Heritage of the Church Mission Society", International Bulletin of Missionary Research, April 1999 http://www.internationalbulletin.org/issues/199 9-02/1999-02-050-ajayi.pdf, p 50
Third, the Evangelicals emerged as a denomination with the vision of working from within the Anglican Church, its liturgies and its Episcopal form of government and the connection of the Church to the state. The Evangelicals' association to the Anglican Church earned them the name of Low Churchmen.

A new church-related terminology emerged that differentiated and identified the orientations of each church. The Low Church was distinct from the AngloCatholic High Church and from the Broad Church that evolved later [34]. Writing about the association of the Evangelicals to the Church of England and their work within the established Church, Ajayi writes:

"In deciding to work from within the Anglican Church, the Evangelicals weighed the advantages and disadvantages. Knowing they were unlikely to change the whole Anglican Church to Methodism, they were satisfied to have their views accommodated as consistent with the basic principles of the church as enunciated at the time of the Reformation [35]."

The Evangelicals were content by securing their position within the Anglican Church and entertained optimism that they would gain to their side the influence of the Church with its strong ties to the State to effect social change. With such vision and approach, the Evangelicals believed that their presence within the Anglican Church was more advantageous than if they were outside. On the approach adopted by Evangelicals, Ayaji further argues:

$$
\begin{aligned}
& \text { 34- J. F. Ade. Ajayi, Ibid, p } 50 \\
& \text { 35- Idem. }
\end{aligned}
$$

"In this way, they balanced their emphasis on the Christian responsibility of saving individual souls with the collective responsibility of Christ-and of the Christian church to save the whole society and, ultimately, humankind. In the work of evangelization in foreign missions, while tolerating the constraints that episcopacy and state power constituted, they were able to exploit the state connection, and they became champions of royal patronage and imperial expansion [36]."

With the foundation of the Society for the Propagation of the Gospel (SPG) (1701) Christian mission was carried to a British colony in America; its prominent missionaries were Charles and John Wesley. The motivation of the Evangelicals, at the time, was not yet fired by the enthusiasm of foreign mission. Their fixed priority was the evangelization inside Britain. The two missionary organizations within the Anglican Church; The (SPG) and the Society for the Propagation of Christian Knowledge (SPCK) (1698) concentrated the bulk of their work on the British colonies in 
America, the West Indies, and relatively to India through Danish missionaries.

The conversion of William Wilberforce to Evangelicalism in 1786 with his yearning for the abolition of the slave trade led to his association with the Clapham Sect (the 1780s-1840s) who were to become the founders of the Church Missionary Society. The Clapham group was composed a small gathering of clergymen and powerful laymen; it was headed by the Reverend John Venn (1834 -1923). Among its other influential members were Charles Grant (1746-1823) of the East India Company, Thomas Clarkson (1760-1846 ) and Zachary Macaulay(1800-1859) of the Sierra Leone Company, and Lord John Shore Teignmouth (1751-1834), who served as former governor-general of India.

36- J. F. Ade. Ajayi, Ibid, p 50

"It was a combination of their interests in India, Africa, and the antislavery campaign that moved them to favour a rekindling of the fire of foreign missions, and the establishment in 1799 of the Society for Missions to Africa and the East, soon to be known as the Church Missionary Society [37]."

Foundation of the Church Missionary Society (1799)

The Church Missionary Society was founded by the members of the Clapham group, also referred to as the Eclectic Society (1783), who met in the vestry of St. John's Chapel, Bedford Row between 1786 and 1796. They discussed questions relating to their missionary obligations. The members of the Eclectic Society were motivated by the idea of the propagation of the Gospel to the Bengal. The plan is that of Charles Grant (1746-1823), George Udny, and David Brown (1763-1812), it was sent from India to William Wilberforce and Charles Simeon (1759-1836) in $1787[38]$.

A member of the Eclectic Society, namely, Charles Simeon formulated the question in 1796 as follows: "With what propriety, and in what mode, can a Mission be attempted to the Heathen from the Established Church?" Four years later on March 18, 1799, John Venn's question was: "What methods can we use more effectually to promote the knowledge of the Gospel among the Heathen?" On the same occasion, John Venn laid down the following principles:

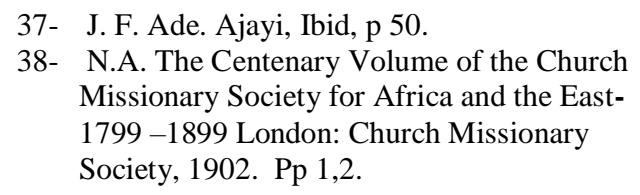

1. "Follow God's leading and look for success only from the Spirit.

2. Under God, all will depend on the type of man sent forth.

3. Begin on a small scale.
4. Put money in the second place, not the first.

5. The Mission should be founded on the Church principle, not the High Church principle. (add a note; "thus differentiating it from the London Missionary Society on the one hand, and the S.P.G. on the other, though it was not intended to come into collision with either."

6. That it is a duty highly incumbent upon every Christian to endeavour to propagate the knowledge of the Gospel among the Heathen.

7. That as it appears from the printed Reports of the Societies for Propagating the Gospel and for Promoting Christian Knowledge that those respectable societies confine their work to the British Plantations in America and to the West Indies, there seems to be still wanting in the Established Church a society for sending missionaries to the Continent of Africa, or the other parts of the heathen world."

8. "That the persons present at this meeting do form themselves into a Society for that purpose, and that the following rules be adopted."

9. "That a Deputation is sent from this Society to the Archbishop of Canterbury as Metropolitan, the Bishop of London as Diocesan, and the Bishop of Durham as Chairman of the Mission Committee of the Society for Promoting Christian Knowledge, with a copy of the Rules of the Society, and a respectful letter[39]."

\section{9- John H. G. Verton. The English Church in the Nineteenth Century. (1 800-1 833)/ London, 1894. p 269.}

By 1812, the name of "Church Missionary Society" became the official name of the Society, its laws were revised and it was decided that the twentyfour elected members of the Committee should be laymen and that all subscribing clergymen should be members of the Committee. Henry Martin (1781- 1812) was CMS's first English corresponding candidate. As a chaplain of the East India Company, his work in India and Persia is described as one of the most valuable labours in the history of the Society [40].

The pioneering work of the CMS was not free from challenges that ranged between indifference to the opposition. The first decade in the Society's history was marked by the sending of only a few missionaries. Their number amounted to six, but, eventually, it increased rapidly. One of the basic characteristics in the work of the CMS at the debut of its enterprise was the lay character of its worker [41]. The Church Missionary Society's beginning of missionary activity is described a one: "... it had been feeble and gave no promise of that great subsequent development which has at length won for it undisputed and universal recognition as the greatest of British Protestant missionary organizations [42]."

40- N.A. The Centenary., pp1, 2 
41- 46- Stock, Vol, III, p 5.

42- 47- Rev. R. Wardlaw Thompson, p 34.

The members of the Society had to wait sixteen months after their foundation of the Society to receive the approval of the Archbishop of Canterbury, and for another four years before candidates could be sent for missionary service [43]. Among the difficulties encountered by the CMS during its early work was the ordination for its Priests. Two of the Society's workers needed to be ordained, but at this early stage, "the bishops had not yet smiled for ordination upon the new Society at all:

"Even when these were approached through personal friends, ordination was still refused for the reason that the candidates worked outside their own dioceses [44].

The Society's Committee was emphatic in their acknowledgement to German Lutherans of the Basel Seminary. The number of the CMS missionaries in the first fifteen years was twenty-four among which seventeen were Germans. Among the seven Englishmen, only three could be ordained. An important member among them was William Jowett, the first University graduate on the Society's role, and the first missionary to Muslims [45].

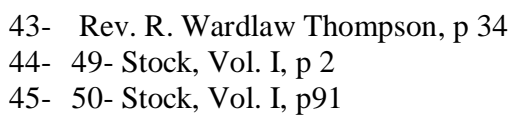

The CMS's voluntary status about which it was proud, led to hostility among members of the Established Church that went on for many years. Nevertheless,

"It was one of Henry Venn's achievements to overcome that suspicion and persuade the Church of England to value the society as playing a vital element in the missionary task within the established church."46

Kevin Ward argues that: "The Venn ideal was trimmed to aid CMS participation in the growing sense of a worldwide Anglicanism." Working within the growing worldwide Anglicanism added a sense of identity to the emerging Society and a praiseworthy initiative. Ward writes:

"The idea of a global Anglican communion owed much of its vigour to the new sense of catholicity inculcated by the Oxford movement"[47].

The emergence of the Anglican Communion was in fact due to the expansion of the Church of England, which went in parallel with that of the British Empire in the nineteenth century. It is observed that this period marked an alarming absence for providing pastoral care in the colonies. The remedy seems to have come from the military and colonial establishment rather than from the Church [48].

46- Kevin Ward, "The Legacy of Eugene Stock, International Bulletin of Missionary Research" April 1999. p 75.

47- Ibid, $\mathrm{p} 76$.

48- Alan Peter Beckman, p 26.

The Church Missionary Society's work spread to important and vast areas around the world. For the success and the maintaining of its missions, a policy was adopted touching to the different spheres of missionary activity. The policy was conducted through successive CMS secretaries during the centenary of the Society's history from 1799 to 1899 . Henry Venn and Joseph Pratt stand as the most outstanding figures in the centenary history of the Society.

In the genesis of the Society, the founders were clear and vocal about how their vision of mission. Though it was stated that the Society's work would go on Evangelical lines, the founders of the Society were also emphatic about carrying on their missionary work "on more strictly ecclesiastical lines [49].

The slow beginning of the CMS, due to the early circumstances surrounding it, was, eventually, to go through a period of great development that: "won for it undisputed and universal recognition as the greatest of British Protestant missionary organizations[50]." This development is attributed to the strategic policy adopted by the CMS. Henry Venn elaborated a strategic missionary policy known as Euthanasia. The latter emphasizes the following:

"A Native Church, with Native bishops and clergy and synods and canons and formularies, independent of the Church of England, though an integral part of the Anglican Communion [51].

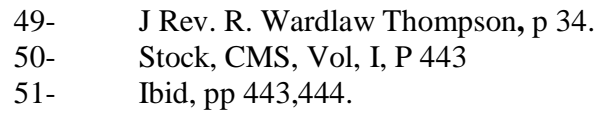

The Euthanasia policy proved slow in achieving that missionary principle due to some complicated problems encountered in the fulfilment of the policy. Nevertheless, Euthanasia is considered as the most important work of the CMS for achieving its goals [56]. Euthanasia might have been slow in achieving the goals, but it was a 'slow but sure' policy because, by the CMS Centenary, many of the churches in Africa and India achieved Euthanasia. This policy, while, de-paternalizing the missions, they were kept tied to the CMS and the Anglican Church through the umbilical cord which is the Anglican Communion and Anglicanism.

\section{The Church Missionary Society's Work in the Muslim World}


The Church Missionary Society's stations around the world touched to the three continents; Africa, Asia and America. After a centenary of missionary activity, the CMS Missions achieved important results in the Christianization of the world through education, medical work and the building of churches and hospitals.

Among the areas of prominent interest to the CMS was the Muslim world. The CMS mission to Muslims was possible thanks to the establishment of the Mediterranean Mission in (1815). The Mission extended its work to Palestine, Persia (Iran), Iraq, Egypt, Ethiopia (Abyssinia), and Sudan.

The Church Missionary Society's interest for starting a mission in the Levant began by Claudius Buchanan (1766-1815) who called the attention of the Society to the region in 1811. In 1815, William Jowett (1785-1855), first English clergyman and an Oxford graduate, was sent by the CMS to start a Mediterranean Mission. However, at this early stage, the CMS instruction focused mainly on an enquiry about the state of the religion of the Oriental Christians and their churches.

The CMS approach to the Oriental churches was deemed an elementary step towards starting a Mission to Muslims. The CMS Mission to Muslims through the Mediterranean Mission started by the sending of missionaries to Greece, Turkey, Asia Minor, Syria and Egypt. The missionaries were welcomed by the respective Patriarchs and Bishops, and their work led to the establishment of a printing press at Malta which led; accordingly, to the distribution of Bibles, tracts and school-books. However, the wars that erupted in Greece in 1821 and the aftereffect situation put an end to that early active missionary work in the Turkish Empire. The mission lasted from 1819 to 1821 and the missionaries returned to their country.

The C.M.S' early efforts, to reach the Muslims in the Near East, were through the Constantinople Mission in 1854 which managed to reap some converts. At that time the SPG was also active in Turkey. The new converts were employed to work by the CMS and the SPG.

After the Crimean War (1853-1856); two German missionaries, Sigismund Koelle (1820-1902), a former active missionary in West Africa, and Pfander or Abdel Masih from India, joined Turkey for evangelistic work. Their efforts led to several conversions, but eight years later, the Mission was suppressed by the Sultan [52].

In Palestine, the CMS work resulted in the ordination of three pastors by1874; namely, Seraphim Boutaji, Michael Kawar, who received Anglican orders from Bishop Gobat (1799-1879); and Chalil Jamal. The newly ordained pastors belonged to the Greek Catholics; a small community which seceded from the Greek to the Roman Church [53].

In 1862, the CMS was invited to start work at Nazareth and Jerusalem. As a result, a special fund for the erection of a church began to be raised. When the Church was built Bishop Gobat was appointed for service in October 1871. Missions to Muslims constituted one of the special interests to General Lake. He realized that several of the missionaries engaged in Missions to Muslims happened to be present in England. He seized the opportunity to arrange a twodays Conference on the subject of "Missions to Muslims". The Conference was entitled "The Mohammedan Conference" and was held at the CMS House on October 1875. By adopting the theme of the Conference it was emphasized that the term Muslims pertained not on only the Muslims of the Levant, but even those of Africa and India formed an integral part of it. A number of speakers contributed to this Conference among them: Bishop Gobat and many others. The Conference expressed a common concern and anxiety as to their universal neglect of Mission to the Muslims [54].

$\begin{array}{ll}\text { 52- } & \text { Stock, Vol. III, p } 137 . \\ 53- & \text { Idem } \\ 54- & \text { Idem }\end{array}$

The outcome of the Conference (1875) was the preparation and submission of plans for extended work in most of the fields representing the CMS, There was a resolute determination to invest efforts: "to carry the General Gospel to the powerful Mohammedan nations, Mandigoes, Fulahs, ...." [55].

With respect to Egypt, in 1825, the CMS sent five missionaries all of whom were Germans from the Basel Seminary, Samuel Gobat was among them. They first landed at Alexandria and gave themselves to the learning of the Arabic language. When Gobat and one of the missionaries went to Abyssinia, the three others inspected the state of Coptic schools and churches. Their evangelistic activity consisted of distributing portions of the Bible which were in the process of translation by William Jowett. The ultimate aim of this group of missionaries was to bring Muslims to Christianity, but they knew how Muslims were resistant and opposed to their preaching.

In 1862 The CMS decided to stop its mission in Egypt for the lack of funds. And the School was reopened during the British occupation to Egypt. The CMS Annual Report of Society shows the clear distinction between the missionary effort deployed from 1882; the British occupation to Egypt and the CMS work in the first half of the nineteenth century.

The Church Missionary Society founded in 1797 celebrated its Centenary in 1899. By the close of the nineteenth century, the Society demonstrated ability 
in founding and caring for its Mission in the different parts of the American, African and Asian Continents. The missionary operations it had all over the world made it one of the most important missionary societies of the Church of England, or as pointed out, "its right arm". In its undertaking to its missions, the CMS was careful about the implementation of Henry Venn's Euthanasia policy, the aim of which was the building native churches that would be independent, selfsupporting and self-governing, but remaining within the Anglican Communion.

The CMS was decisive in establishing its Mission to Muslims and even expressed anxiety for its delay in starting it. Its early Missionary work in the Muslim world through the Mediterranean Mission is rudimentary for the understanding of the CMS later missionary activities in the Muslim world in the Twentieth and Twenty-First Centuries.

Stock, Vol. III, p143.

\section{REFFERENCE}

1. Beckman, A. P. (2011). A clash of churchmanship? Robert Gray and the Evangelical Anglicans 18471872.

2. Bready, J. W., England, B., \& Wesley, A. (1938). The Evangelical Revival and Social Reform.

3. http://abolition.e2bn.org/people_24.html

4. John, D.(1983). "The Great Evangelical Awakening of the Eighteenth Century" New Creation Publication Inc. PO Box 403, Blackwood, South Australia 5051 1983, First published December 1983 ㄷ 1983 John Dunn ISBN 086408 0077

5. http://justus.anglican.org/resources/bcp/Nonjurors. $\mathrm{htm} / /$ Accessed on 29/09/2017.
6. http://www.biblestudytools.com/dictionary/convoc ation/ / Accessed on 20/09/2017.

7. https://www.britannica.com/topic/Clapham-Sect

8. https://www.britannica.com/topic/AnglicanEvangelical\#ref84601. Accessed on 21/09/

9. https://www.churchofengland.org/media/2002929/ healing $\% 20$ the $\% 20$ past $\% 20$ building $\% 20$ the $\% 20$ fut ure.pdf,

10. http://www.cofhconnexion.org.uk/history/ Accessed on 29/09/2017

11. https://en.oxforddictionaries.com/definition/presbyt erianism

12. https://www.ministrymagazine.org/ar chive/1977/10/a-conservativeapproach-to-theology.

13. J. F. Ade. Ajayi. "From Mission to Church: The Heritage of the Church Mission Society", International Bulletin of Missionary Research, April 1999 http://www.internationalbulletin.org/issues/199902/1999-02-050-ajayi.pdf

14. Kevin Ward, "The Legacy of Eugene Stock", International Bulletin of Missionary Research " April 1999

15. N.A. The Centenary Volume of the Church Missionary Society for Africa and the East- 1799 1899. London: Church Missionary Society, 1902.

16. Eugene, S. (1899). History of the Church Missionary Society. Its Environment, Its Men and Its Work, London Church Missionary Society, Salisbury,

17. Eugene, S. (1899). History of the Church Missionary Society: Its Environment, Its Men and Its Work, London Church Missionary Society, Salisbury,

18. John, H. G. Verton. (1894).The English Church in the Nineteenth Century.(1 800-1 833)/.London, 1894. 